\title{
Two new species of Dryinidae (Hymenoptera: Chrysidoidea) from areas of Atlantic Rainforest at São Paulo State, Brazil
}

\author{
Martins, AL. ${ }^{a *}$, Lara, RIR. ${ }^{b}$ Perioto, $N W^{b, c}$ and Olmi, M. ${ }^{d}$ \\ aPrograma de Pós-Graduação em Entomologia, Universidade Federal do Paraná - UFPR, \\ CP 19020, CEP 81531-980, Curitiba, PR, Brazil

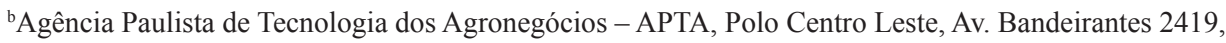 \\ CEP 14030-670, Ribeirão Preto, SP, Brazil \\ 'Programa de Pós-Graduação em Agronomia - Entomologia Agrícola, Faculdade de Ciências Agrárias e Veterinárias, \\ Universidade Estadual Paulista "Júlio de Mesquita Filho" - UNESP, Via de Acesso Prof. Paulo Donato Castellane, \\ CEP 14888-900, Jaboticabal, SP, Brazil \\ ${ }^{\mathrm{d}}$ Tropical Entomology Research Center, Via De Gasperi 10, I-01100 Viterbo, Italy \\ *e-mail: andrelmartinsbiol@hotmail.com
}

Received: October 1, 2013 - Accepted: November 6, 2013 - Distributed: May 31, 2015

(With 12 figures)

\begin{abstract}
Two new species of Dryinidae are described and illustrated: Dryinus auratus Martins, Lara, Perioto \& Olmi sp. nov. and Gonatopus mariae Martins, Lara, Perioto \& Olmi sp. nov., both from areas of Atlantic Rainforest at São Paulo State, Brazil. Keys to species are provided.
\end{abstract}

Keywords: Dryinus, Gonatopus, Malaise trap.

\section{Duas novas espécies de Dryinidae (Hymenoptera: Chrysidoidea) de áreas de Mata Atlântica do Estado de São Paulo, Brasil}

\section{Resumo}

Duas novas espécies de Dryinidae (Hymenoptera: Chrysidoidea) de áreas de Mata Attântica do Estado de São Paulo, Brasil. Duas novas espécies de Dryinidae (Hymenoptera: Chrysidoidea) são descritas e ilustradas: Dryinus auratus Martins, Lara, Perioto \& Olmi sp. nov. e Gonatopus mariae Martins, Lara, Perioto \& Olmi sp. nov., ambas provenientes de áreas de Mata Atlântica do Estado de São Paulo, Brasil. São fornecidas chaves para as espécies.

Palavras-chave: Dryinus, Gonatopus, armadilha Malaise.

\section{Introduction}

Dryinidae (Hymenoptera: Chrysidoidea) are parasitoid wasps found worldwide, whose larvae develop on nymphs and adults of Auchenorrhyncha (Hemiptera) (Olmi, 2006); there are about 1700 described species, distributed in 14 subfamilies and 48 genera (Olmi and Guglielmino, 2010, 2012; Xu et al., 2013).

Dryininae comprises about 340 species distributed in nine genera, of which five are reported for the Neotropics; Dryinus Latreille, 1804 are present in all zoogeographical regions and comprise about 290 species (Olmi et al., 2011; Olmi and Virla, 2014), of which about 120 are reported from the Neotropics and about 40 from Brazil (Olmi, 2009; Coelho et al., 2011; Olmi and Virla, 2014). Dryinus is divided into four species-group: autumnalis, constans, lamellatus and ruficauda (Olmi et al., 2011). Dryinus of the constans group (group 1 of Olmi and Virla,
2014), comprises about 40 species, 12 from Brazil and it is characterized by the notaulice at least partly visible and enlarged claw, much longer than arolium, with one subapical tooth and never with a broad apical lamella (Olmi et al., 2011; Olmi and Guglielmino, 2011; Olmi and Virla, 2014).

Gonatopodinae has cosmopolitan distribution and about 560 species distributed in nine genera, eight reported for the Neotropical region. Gonatopus Ljungh, 1810, also cosmopolitan, has about 440 species divided into 12 groups of species, 160 species are reported from the Neotropics and 30 from Brazil (Olmi and Virla, 2014).

This study aimed to describe new species of Dryinus and Gonatopus collected in áreas of Atlantic Rainforest at São Paulo State, Brazil. 


\section{Material and Methods}

The specimens were collected at Parque Estadual Intervales $\left(24^{\circ} 16^{\prime} 28.0^{\prime}\right.$ 'S 48 $25^{\prime} 14.8^{\prime}$ W), at Ribeirão Grande municipality, and at Parque Estadual da Serra do Mar, Núcleo Santa Virgínia (23¹9'17.9”S 4505'42.9”W), at São Luis do Paraitinga municipality, both of them with Malaise traps (model Townes, 1972) in areas of Atlantic Rainforest at São Paulo State, Brazil. They were dehydrated in a Leica EM CPD30 critical point dryer and later mounted on cards on entomological pins.

Observations and descriptions were made using a Leica MZ 9.5 stereomicroscope; the colour images were obtained with Leica DFC295 digital camera attached to a Leica M205C APO stereomicroscope; specimens were illuminated with high diffuse dome illumination Leica LED5000 HDI. The serial images from different layers were combined with Helicon Focus software (version 5.3). Digital scanning electronmicroscope (SEM) photographs weret aken with a FEI Quanta TM 250 SEM in low vacum mode. The figures were prepared using Adobe Photoshop (version 11.0).

The morphological terminology follows Olmi and Virla (2014), except for the forewing radial vein, herein termed as Rs; the integument sculpture follows Eady (1967).

The identifications were made using the keys proposed by Olmi (2006) and Olmi and Virla (2014).

Abbreviations are as follows: OOL, ocellar-ocular distance; POL, post-ocellar distance; OL, ocellar line; OPL, ocellar-occiptal line; Rs, radial vein.

List of repositories: MZSP - Museu de Zoologia da Universidade de São Paulo, São Paulo, Brazil (C.R.F. Brandão, curator); LRRP - Coleção Entomológica do Laboratório de Sistemática e Bioecologia de Parasitoides e Predadores da APTA Ribeirão Preto, Ribeirão Preto, SP, Brazil (N.W. Perioto, curator).

\section{Taxonomy}

Dryinus auratus sp. nov. Martins, Lara, Perioto \& Olmi

Figures 1-7

Diagnosis. Body predominantly golden yellow; forewing with a transversal band; head convex, granulate; frontal line absent; occipital carina incomplete.

Description. Holotype female (Figure 1). Fully winged; length $5.2 \mathrm{~mm}$. Body predominantly golden yellow, except by a spot in outer side of mesocoxa, dorsal petiole and basal portion of the first abdominal tergite black. Antenna clavate; length of antennal segments in following proportions: $8: 6: 24: 14: 11: 9: 8: 8: 7: 8.5$. Head dull, granulated; frontal line absent (Figure 2); occipital carina incomplete, laterally not reaching eyes, not present on temple (Figure 3); $\mathrm{POL}=2$; $\mathrm{OL}=3 ; \mathrm{OOL}=7 ; \mathrm{OPL}=2.5 ; \mathrm{TL}=4$; greatest breadth of posterior ocellus about as long as OPL; temple present (Figure 3). Palpal formula 6/3. Pronotum coriaceous, with some longitudinal keels on lateral regions, crossed by two slight transverse impressions; disc little humped; posterior collar short; pronotal tubercle not reaching the tegula. Scutum dull, granulated, rugose at posterior third.

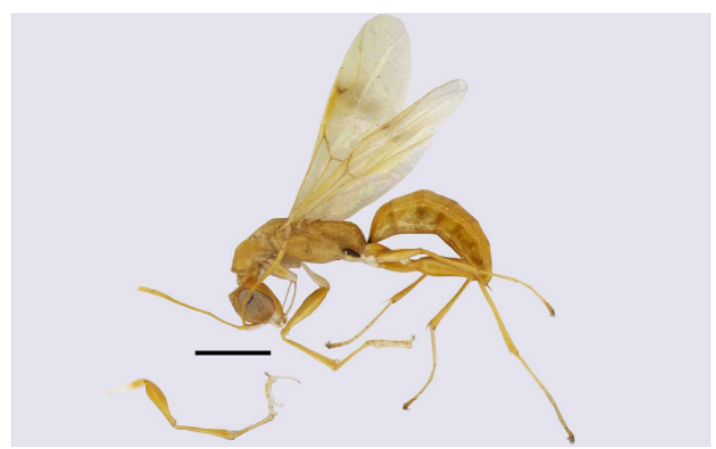

Figure 1. Dryinus auratus sp. nov. Female. 1. Habitus, scale bar $=1 \mathrm{~mm}$.

Notauli complete, posteriorly separated, hardly visible; minimum distance between notauli longer than POL (4:2). Scutellum dull, granulated (Figure 4). Metanotum dull, granulated and rugose; propodeum reticulate rugose (Figures 5 and 6), with two median subparallel keels on dorsal surface; posterior surface with two longitudinal keels. Forewing with one hardly visible dark transverse band beneath the pterostigma; distal part of stigmal vein longer than proximal part (21:9). Protarsal segments in following proportions: 24:3:5:12:21. Protarsus (Figure 7) with segment 3 produced into hook; segment 5 with two rows of three (proximal) + six lamellae (Figure 7); distal apex with about 11 lamellae; enlarged claw with one large subapical tooth and four lamellae + one bristle. Tibial spurs $1 / 1 / 2$.

Male. Unknown.

Host. Unknown.

Distribution. São Paulo State, Brazil.

Remarks. The new species belongs to Dryinus group constans by the presence of notauli and the enlarged claw provided of one large subapical tooth; it can be included in the key to the females of the Neotropical Dryinus species of group constans presented by Olmi and Virla (2014) by replacing the initial couplets $1-3$, as follows

\section{Occipital carina absent........ D. constans Olmi, 1984}

- Occipital carina present, complete or incomplete ..... 2

2. Mesosoma totally or almost totally testaceous or testaceous-reddish .................................................... 3

- Mesosoma mostly or totally black (if prothorax not black and rest of mesosoma black, mesosoma considered mostly black). 8

3. Enlarged claw with subapical tooth situated very close to distal extremity (Plate 89D in Olmi and Virla, 2014; Figure 7). .. $3^{\prime}$

- Enlarged claw with subapical tooth situated farther from distal extremity (Plates 86D-G, 91B in Olmi and Virla, 2014). ... 4

3'. Enlarged claw with bristles, without lamellae (Plate 89 D in Olmi and Virla, 2014).D. citricolus Olmi, 1984.

- Enlarged claw with one row of lamellae (Figure 7) D. auratus sp. nov. 


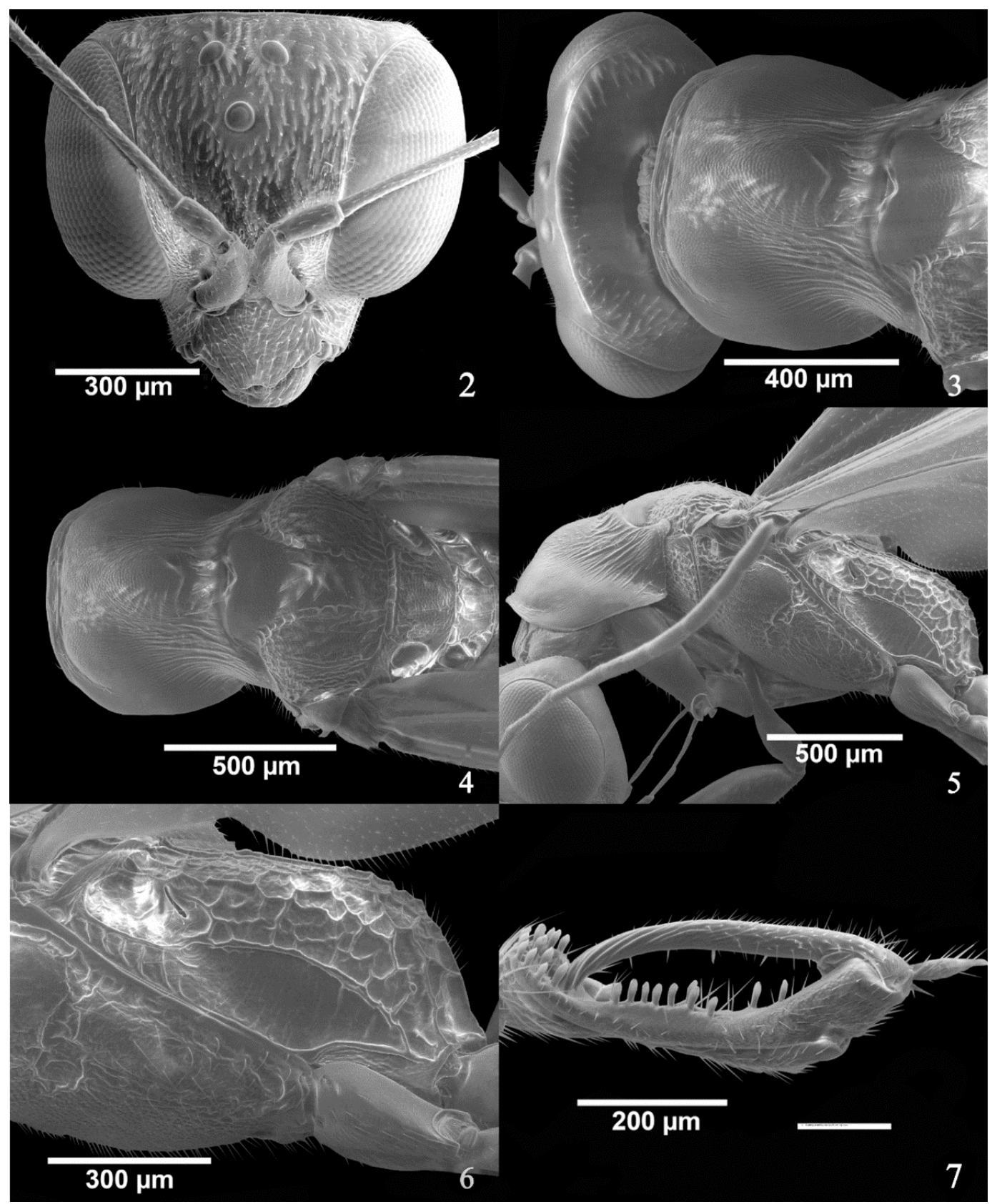

Figures 2-7. Dryinus auratus sp. nov. Female. 2. Head, frontal view. 3. Head, dorsal-posterior view. 4. Mesosoma, dorsal view. 5. Mesosoma, lateral view. 6. Propodeum, lateral view. 7. Claw.

Etymology. The name of this species refers to the gold yellow coloration of the body.

Material examined. Holotype female, BRAZIL, S[ão] P[aulo], Ribeirão Grande, Parque Estadual Intervales,

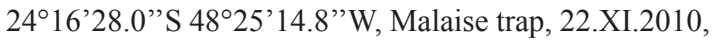
N.W. Perioto and team legs. (MZSP).

Gonatopus mariae sp. nov. Martins, Lara, Perioto \& Olmi

Figures 8-12
Diagnosis. Head excavated, granulated; frontal line incomplete; occipital carina incomplete, absent near clypeus; pronotum smooth, shiny; enlarged claw with one large subapical tooth and onde row of 6-7 lamellae; head and mesosoma predominantly ferruginous, metasoma brown.

Description. Holotype female (Figure 8). apterous; length $3.4 \mathrm{~mm}$. Head ferruginous, except anterior margin of clypeus and antenna brown; mesosoma ferruginous; legs brown, except part of procoxa and protrochanter testaceous; metasoma brown. Antenna clavate; length of antennal segments 
in following proportions: $10: 5: 12: 6: 5: 5: 4.5: 4: 4.5: 6.5$. Head excavated, dull, granulated; frontal line incomplete, absent near the clypeus (Figure 9); $\mathrm{POL}=1 ; \mathrm{OL}=3 ; \mathrm{OOL}=8$; occipital carina shortly present on sides of posterior ocelli, laterally not reaching the eyes (Figure 9). Palpal formula 6/3. Pronotum shiny, smooth, crossed by strong transverse furrow

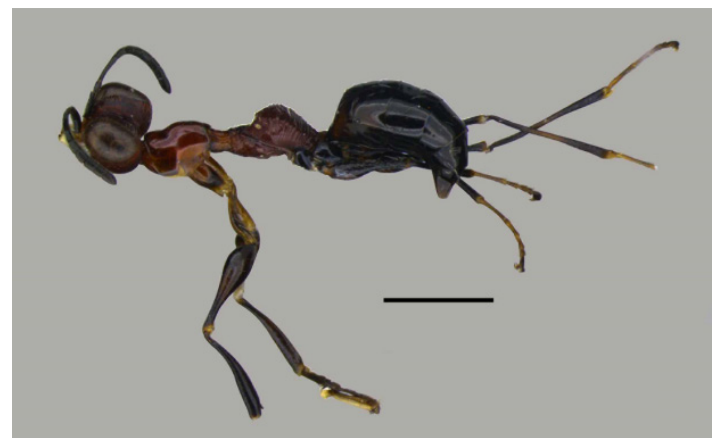

Figure 8. Gonatopus mariae sp. nov. Female. Habitus (Holotype), scale bar $=1 \mathrm{~mm}$.
(Figure 10). Scutum shiny, sculptured by few longitudinal keels, with two lateral pointed apophyses (Figure 10). Metanotum hollow behind the scutellum. Metathorax + propodeum shiny, with anterior surface unsculptured and posterior surface strongly transversely striate (Figure 10). Meso-metapleural suture distinct and complete, step-shaped. Mesopleuron unsculptured (Figure 11); Metapleuron strongly transversely striate (Figure 11). Length of protarsal segments in following proportions: 14:3:5:15:24. Segment 5 of protarsus (Figure 12) with one row of 13-18 lamellae; distal apex with about of 13 lamellae. Enlarged claw with one large subapical tooth and one row of 6-7 lamellae. Tibial spurs 1/0/1.

Male. Unknown.

Host. Unknown.

Distribution. São Paulo State, Brazil.

Remarks. The new species belongs to Gonatopus group 4 (Olmi and Virla, 2014) by the pronotum crossed by a strong transverse furrow, the enlarged claw provided of one large subapical tooth and lamellae and by the palpal formula 6/3; it can be included in the key to the females of the Neotropical

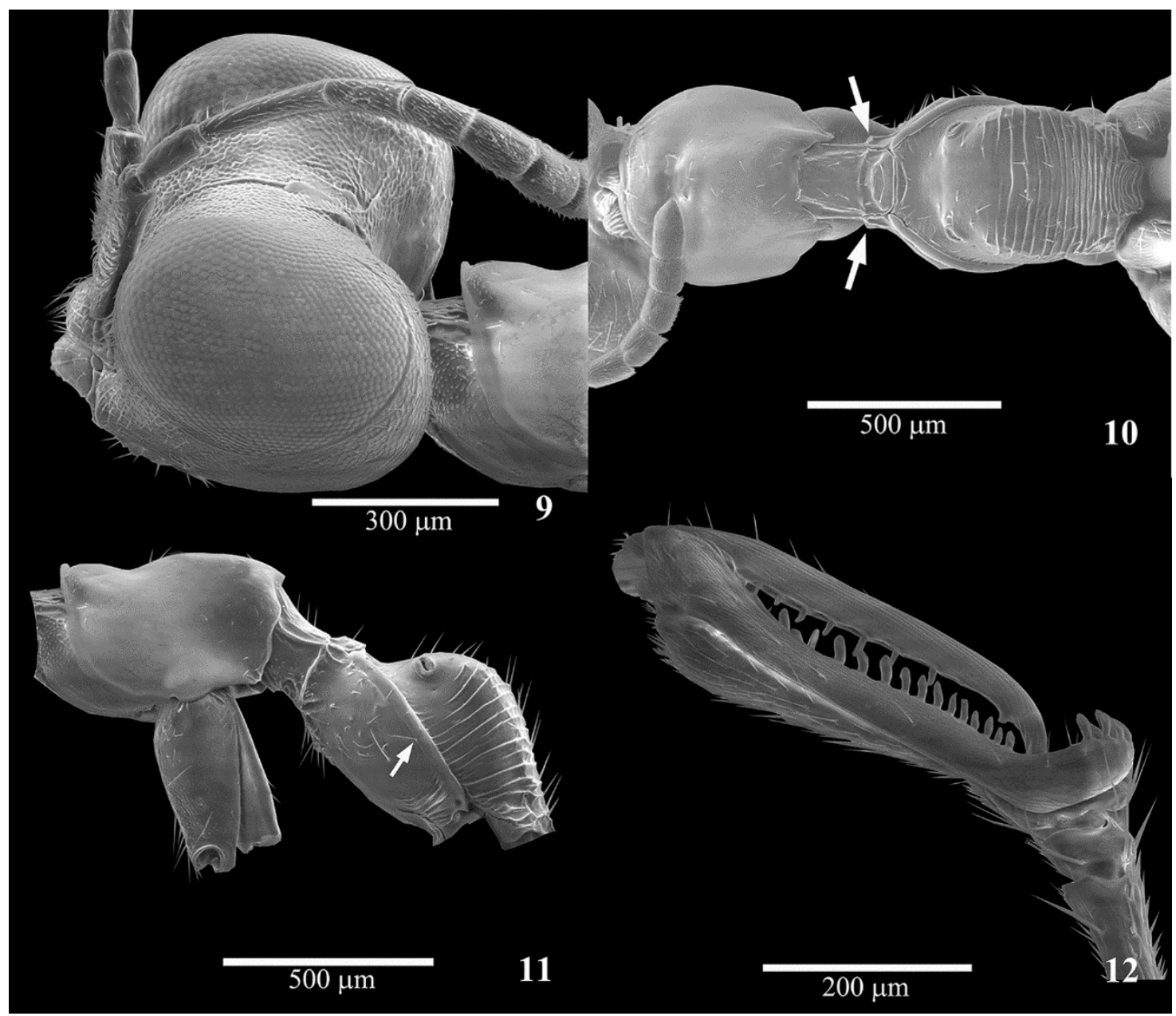

Figures 9-12. Gonatopus mariae sp. nov (Paratype). Female. 9. Head, dorsolateral view. 10. Mesosoma dorsal view. 11. Mesosoma and propodeum, lateral view. 12. Claw. 
Gonatopus species of group 4 presented by Olmi and Virla (2014) by replacing the final couplets $12-14$ as follows:

12. Scutum with two lateral pointed apophyses (Plate 167A in Olmi and Virla, 2014). .. 13 -Scutum without lateral pointed apophyses (Plate 168F in Olmi and Virla, 2014) .. 14

13. At least anterior half of anterior surface of metathorax + propodeum sculptured by numerous fine and transverse striae......... G. testaceus Cameron, 1888 - Anterior surface of metathorax + propodeum completely unsculptured, not transversely striate. 13 '

13'. Metanotum not hollow behind scutellum G. bellottii (Olmi, 1984)

- Metanotum hollow behind scutellum (Figure 10) G. mariae sp. nov.

14. Metanotum with sides protruding; protrusions pointed; body mostly testaceous-reddish G. menkei (Olmi, 1984) - Metanotum with sides rounded (Plate 168F in Olmi and Virla, 2014), not protruding; body mostly black ..G. punensis (Olmi, 1991)

Etymology. This species is named in honor of Maria da Consolação Martins (in memoriam), mother of the first author.

Material examined. Holotype female. BRAZIL, S[ão] P[aulo], São Luis do Paraitinga, Parque Estadual da Serra do Mar, Núcleo Santa Virgínia, 2319'17.9'S 4505'42.9'"W, Malaise trap, 22.X.2010, N.W. Perioto and team., legs. (MZSP); Paratype. 1 female, same locality label as holotype (LRRP).

\section{Acknowledgements}

We are grateful to the Instituto Nacional de Ciência e Tecnologia dos Hymenoptera Parasitoides da Região Sudeste Brasileira (INCT - Hympar/Sudeste - CNPq/ FAPESP/CAPES) for the financial support, Luciana Bueno dos Reis Fernandes for the SEM photomicrographs and Eduardo Mitio Shimbori for the assistance with the plates.

\section{References}

COELHO, BW., AGUIAR, AP. and ENGEL, MS., 2011. A survey of Dryinidae (Hymenoptera, Chrysidoidea) from Caxiuanã, Amazon Basin, with three new taxa and keys to genera and species. Zootaxa, no. 2907, p. 1-21.

EADY, RD., 1967. Some illustrations of miscrosculpture in the Hymenoptera. Proceedings of the Royal Entomological Society, no. 42 , p. $66-73$.

OLMI, M. and GUGLIELMINO, A., 2010. Description of Erwiniinae, new subfamily of Dryinidae from Ecuador (Hymenoptera: Chrysidoidea). Zootaxa, no. 2605, p. 56-62.

OLMI, M. and GUGLIELMINO, A., 2011. Revision of fossil species of Dryinus belonging to lamellatus group, with description of a new species (Hymenoptera, Dryinidae). ZooKeys, no. 130, p. 505-514. PMid:22259296.

OLMI, M. and GUGLIELMINO, A., 2012. A contribution to the knowledge of Dryinidae from Late Eocene Baltic amber (Hymenoptera: Chrysidoidea), with description of new subfamily, Protodryininae subfam.nov. Zootaxa, no. 3351, p. 15-26.

OLMI, M. and VIRLA, EG., 2014. Dryinidae of the Neotropical region (Hymenoptera: Chrysidoidea). Zootaxa, vol. 3792, no. 1, p. 1-534. http://dx.doi.org/10.11646/zootaxa.3792.2.1. PMid:24869997

OLMI, M., 2009. Catalogue of Dryinidae of Brazil (Hymenoptera Chrysidoidea). Frustula Entomologica, vol. 45, no. 37, p. 1-29.

OLMI, M., GUGLIELMINO, A. and VOLLARO, M., 2011. Revision of fossil species of Dryinus belonging to constans group, with description of a new species (Hymenoptera: Dryinidae). Zootaxa, no. 2981, p. 43-55.

OLMI, M., 2006. Familia Dryinidae. In FERNÁNDEZ, F. and SHARKEY, MJ. (Eds.). Introducción a los Hymenoptera de la región Neotropical. Bogotá: Sociedad Colombiana de Entomologia/ Universidad de Colombia. p. 7-35.

TOWNES, HA., 1972. A light-weight Malaise trap. Entomological News, no. 83, p. 239-247.

XU, Z., OLMI, M. and HE, J., 2013. Dryinidae of the Oriental region (Hymenoptera: Chrysidoidea). Zootaxa, vol. 3614, p. 1-460. http://dx.doi.org/10.11646/zootaxa.3900.1.1. PMid:24759692 